ISSN:

Print - $2277-0755$

Online - $2315-7453$

(c) FUNAAB 2019

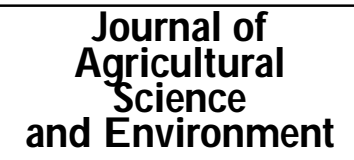

\title{
EFFECT OF ORGANO- BASED FOLIAR FERTILIZER ON CHLOROPHYLL AND NUTRITIONAL QUALITY OF OKRA VARIETIES IN DERIVED SAVANAH OF NIGERIA
}

\author{
*1P.0, AKINTOKUN., 1D.U, AMUOFU AND 1M.R. OSHO
}

1D epartment of Plant Physiology and Crop Production, Federal University of Agriculture, Abeokuta, Nigeria.

*Comesponding Author: akinpius97@yahoo.com Tel: +2348037215443

\begin{abstract}
Cultivation of okra (Abelmoschus esculentus L.) which is a commonly grown vegetable crop in the tropics is constrained by depleting soil fertility. Use of foliar fertilizer as a supplement has been successfully reported in the temperate region hence there is need to determine the effect of foliar liquid fertilizer on okra growth and nutritional quality. Field experiments were conducted at the Abeokuta (Federal University of Agriculture [FUNAAB] ) and Ibadan (National Horticulture Research Institute [NIHORT] ), between May and August 2015 to evaluate the response of two okra varieties to types and rates of organic-based foliar fertilizer application. Experiment was a $2 \times 2 \times 5$ factorial combinations laid out in Randomized Complete Block Design with three replicates at both locations. Factors were okra variety (LD88 and NHae47-4), the fertilizer types (D.I. Grow Green ${ }^{\circledR}$ and D.I.Grow Red®) and four rate of foliar applications (0 [control], 300, 600 and $900 \mathrm{ml} / \mathrm{ha}$ ) while NPK 15:15:15 served as check. The results showed that the D.I.Grow Red(B at $300 \mathrm{~m} / /$ ha produced the higher Ash $(8.23 \%)$, fat $(2.54 \%$,$) , moisture (14.65 \%)$, and carbohydrate $(47.31 \%)$ at Abeokuta while $600 \mathrm{ml} / \mathrm{ha}$ produced significantly the higher ash, crude fibre, moisture and carbohydrate $(9.37 \%, 15.94 \%, 9.13 \%$, and $52.02 \%$ ), respectively in Ibadan. The study concluded that okra variety LD88 had superior growth performance. Application of D.I.Grow Red® at the rate of $300 \mathrm{ml} / \mathrm{ha}$ at Abeokuta and $600 \mathrm{ml} / \mathrm{ha}$ at Ibadan enhance fruit nutritional quality of okra. Therefore, 300 and $600 \mathrm{ml} / \mathrm{ha}$ is recommended to farmers in Abeokuta and Ibadan, respectively.
\end{abstract}

Keywords: Chlorophyll, Ash content (\%), fat content (\%), Crude fibre content (\%), Crude protein content (\%), Moisture content (\%), and carbohydrate content (\%).

\section{IN RODUCTION}

Okra is a vegetable crop that belongs to the genus Abdmoshus family Malvacee and has two main species: caille and esalentus (L.) (Siemonsma 1982). Varieties vary with plant height, maturity date, fruit size and color (Udoh \&al., 2005).

Okra contains protein carbohydrate, and vitamin $\mathrm{C}$ in large quantity (Adeboye and
Oputa, 1996). The essential and nonessential amino acids that okra contains are comparable to Soybean which had grate implication for human health (Ngbede et al.,2014). It was also reported by Eke $\notin$ al., (2008) that fresh fruit is a good source of minerals vitamins, and proteins thus plays a vital role in human diet hence can be consumed boiled and fried cooked the young immature fruits. 
In Nigeria, okra is usually boiled in water resulting in slimy soups and sauces, which are relished. The fruits serve as soup thickeners (Schippers, 2000). The flowers, leaves and buds are also edible. Okra seeds could be dried and the seed is a nutritious condiment that can be used to prepare vegetable curds, or ground and roasted to be used as coffee additive or substitute (Farinde $\notin \mathrm{al}$., 2001). O kra leaves are considered good cattle feed, but this is seldom compatible with the primary use of the plant.

Okra production worldwide is estimated at six million tonnes per year. In West Africa, it is estimated at 500,000 to 600,000 tonnes per year (Burkil, 1997). The total area under cultivation has increased over the years; India is the world largest producer followed by Nigeria and Sudan (Varmudy, 2011). They are cultivated in warm temperate, subtropical and tropical regions over the world (NRC, 2006). O kra is the most important fruit vegetable crop and a source of calories of about $(4550 \mathrm{~K} \mathrm{cal} / \mathrm{kg}$ ) (Babatunde $\notin \mathrm{al}$., 2007).

Fertilizer irrespective of type is vital to crop production and attainment of sufficient food production globally (Shukla and Naik, 1993). Palm \& al; (1993) described organic and inorganic fertilizer as essential tools in okra production. Omotosho and Shittu (2007), reported that fertilizer application rate of $150 \mathrm{~kg} \mathrm{NPK}$ ha-1 for ring method of fertilizer application are effective for the growth and yield of okra while Iyagba (2013) reported that fertilizer application rates of $200 \mathrm{~kg}$ NPK ha-1 and ring method of fertilizer application are effective for the growth and yield of okra.

Reuveni and Reuveni (1995) reported that foliar feeding is an effective method for correcting soil deficiencies and overcoming the short coming that emerge from direct application of fertilizer to the soil due to leaching and transfer nutrients beyond the reach of the feeder root $s$ of the crop. Foliar feeding could be 8 to 10 times more effective than soil feeding and up to 90 percent of a foliar fed nutrient solution could be found in the smallest root of a plant within 60 minutes of application opined Reuveni and Reuveni (1995). The torrential rainfall that characterize the tropical environment which create nutrient deficiency call for alternative way of making the nutrient available to the crop for growth and development. Some foliar fertilizers the contained N.P.K and micronutrients are recommended as the efficient method of ameliorating nutrient deficiencies in vegetables and also increasing yield and quality of crop products (Kannan, 2010; Naz \&al., 2012).

The D .I GROW ${ }^{\circledR}$ is a natural foliar organic fertilizer that is rich in macro and micro nutrients, trace elements and humic acid, improve the growth of various vegetables, fruits and flowers as well as improve the quality of soil (Dynapharm, 2003). The exploration of folia fertilizer in production of okra and their nutritional quality therefore worth investigating. Hence the objective was to determine the effect of foliar fertilizer type and rates application on Chlorophyll and nutritional quality of okra varieties.

\section{MATE RIALS AND METHODS Experimental location}

The experiments were conducted at two different locations in 2015 growing season. The locations were the Directorate of University Teaching and Research Farms (DUFARMS) of the Federal University of Agriculture, Abeokuta a D erived savannah - transition agro ecological zone (7015' N, 3025' E) and at the 
EFFECT OF ORGANO - BASED FO LIAR FERTILIZER ON CHLO ROPHYLL AND ...

National Horticulture Research (NIHORT) search (NIFOR), Benin City.

Ibadan (7022.5 ' N, 3056.5 ' E) forest - transitory agro ecological zone respectively.

\section{N utrient composition of the liquid ferti- lizer}

\section{Source of experimental plant materials}

The Liquid organic fertilizers are made up of The Seeds of okra varieties: (LD 88 and NHae47-4) used for this study were sourced from the National Horticultural Research Institute (NIHORT), Ibadan. They were improved, short duration, erect growing and high yielding cultivars. while D.I.grow organic plus ${ }^{\circledR}$ liquid fertilizers were sourced from Nigerian Institute for Oil Palm Re-

two types, D. I. Grow green ${ }^{\circledR}$ and D.I Grow red ${ }^{\circledR}$. The two types of liquid were formulated from Acadian seaweed (Ascophyllum nodosum), with complete ionic elements, macro ( $\mathrm{N}, \mathrm{P}, \mathrm{K}, \mathrm{Ca}, \mathrm{Mg}, \mathrm{S})$ and micro (Fe, $\mathrm{Ze}, \mathrm{Cu}, \mathrm{Mo}, \mathrm{Mn}, \mathrm{B}, \mathrm{Cl}$ ) iones (Table 1).

Table 1: Composition of the liquid fertilizer from the manual

\begin{tabular}{lll}
\hline ELEMENTS & D.I grow GREEN ${ }^{\circledR}$ & D.I grow RED ${ }^{\circledR}$ \\
\hline $\mathrm{N}(\%)$ & $\mathrm{A}$ & $\mathrm{C}$ \\
$\mathrm{P}(\boldsymbol{\%})$ & 2.35 & 1.85 \\
$\mathrm{~K}(\boldsymbol{\%})$ & 4.44 & 1.85 \\
$\mathrm{Mg}(\mathbf{\%})$ & 1.75 & 3.31 \\
$\mathrm{Fe}(\mathrm{ppm})$ & 0.36 & 0.49 \\
$\mathrm{Mn}(\mathrm{ppm})$ & 867 & 742 \\
$\mathrm{Cu}(\mathrm{ppm})$ & 223 & 587 \\
Zn (ppm) & 144 & 105 \\
Bo (\%) & 0.011 & 383 \\
Mo (\%) & 0.002 & 0.043 \\
Humic Acid & 0.68 & 0.0076 \\
$(\%)$ & & 0.68
\end{tabular}

Source A and C: Organic Plus Fertilizer2003

Pre - planting soil analysis

Composite soil samples collected from each location were analysed at the soil laboratory of institute of Agricultural Research and Training (IA\&RT) to determine the soil physical and chemical properties using the Tropical Soil Biology and Fertility (TSBF) methods of soil and plant analysis (O kalebo eal., 1993). 


\section{Experimental design and treatments}

The experiment was a $2 \times 2 \times 5$ factorial in a split-split-plot arrangement, with three replicates at both locations. The factors were okra varieties (LD 88 and NHae47-4), the fertilizer types (D.I. Grow green $® a n d$ D.I.Grow Red $\AA$ ) and four rates of foliar applications (control (0) , 300, 600 and 900 $\mathrm{ml} /$ ha) while NPK 15:15:15 at 200kg NPK ha-1 (Iyagba eal., 2013) served as check. The main plot consisted of the two okra varieties (LD88 and NHae47-4), sub plot treatments were the two liquid fertilizers D.I. GRO W GREEN ${ }^{\circledR}$ and D.I. GROW RED ® while the sub - sub - plot treatments were rates $(0,300,600,900 \mathrm{ml} / \mathrm{ha}$ and given 20 treatments combination. Total number of plot was 60 plots while the main plot size was $8.4 \mathrm{~m}^{2}$. The total area plot size was $720.5 \mathrm{~m}^{2}$

\section{Land preparation, soil sampling, treat- ment application and cultural practices.}

The land was ploughed twice and harrowed once after ploughing. There was $1 \mathrm{~m}$ between replicates, and $0.5 \mathrm{~m}$ between each plots. The plots were treated with liquid fertilizers D.I. grow green ${ }^{\circledR}$ and D.I. grow red $₫$ after two weeks and four weeks, and these were measured with the aid of $0.2 \mathrm{mls}$ discharged of syringe of liquid fertilizer at the rates of $0,300,600$ and $900 \mathrm{ml} /$ ha to knapsack sprayer which was calibrated to discharge $200 \mathrm{l} /$ ha of water at constant rates. The soil fertilizer (N.P.K. 15:15:15) was applied at $200 \mathrm{~kg}$ NPKha-1 as a check. Three seeds each of the two (NHae47-4 and LD 88) okra varieties were sown per hole and thinned to one plant per stand at two weeks after sowing (WAS). Seeds were sown at the spacing of $60 \mathrm{~cm} \times 40 \mathrm{~cm}$ giving a total number of 1,666 plants/ ha. Weeding was done manually when necessary.

\section{Data collection}

The following data were collected on the okra plants. The okra fruits were ready for first harvest at 7 weeks after sowing. Okra fruits were $h$ arvested at interval of five days.

Chlorophyll content: This was determined using SPAD 500 chlorophyll meter on the tagged plants at 2, 4, 6 and 8WAS.

\section{Proximate analysis:}

The moisture, ash and crude fibre contents of samples of NHae47-4 and LD 88 were determined using Standard Chemical Methods described by Association of Official Analytical Chemistry (AOAC,1990). Soxhlet extraction technique using petroleum ether (40-50 $\mathrm{C}$ ) was used to evaluate the fat contents of the samples (Pearson $\&$ al., 1981). Kjedahl method was used to determine the crude protein contents of the samples as described by (AO AC, 1990).

The contents of carbohydrate of the samples were estimated by difference

$\%$ carbohydrate $=100 \%$ - sum of percentage of moisture, ash, fat, crude fibre and crude protein contents as described by (Akpambang \&al., 2008).

\section{Statistical analysis}

Data collected were analyses using ANOVA (Analysis of Variance) of G enstat D iscovery Statistical Package 2012 and means were separated using least significant difference LSD at $5 \%$ probability level.

\section{RESULTS}

\section{Weather data in Abeokuta and I badan}

In Table 2, total amount of rainfall at Ibadan and Abeokuta experimental field between May and August 2015 were $852.9 \mathrm{~mm}$ and $320 \mathrm{~mm}$ respectively. At Abeokuta and Ibadan, the highest rainfall observed was in June 
EFFECT OF ORGANO - BASED FO LIAR FERTILIZER ON CHLO ROPHYLL AND ...

and May, (165 mm, $321.9 \mathrm{~mm}$ ) respectively, in both $\mathrm{P}$ and $\mathrm{K}$ in the two location hence and the lowest rainfall was in July (157.9 the soil was deficient in the nutrients. $\mathrm{mm})$ and August $(29 \mathrm{~mm})$ respectively. Mean Maximum Temperature at Abeokuta (May to August, 2015) ranged from $29.5^{\circ} \mathrm{C}$ to $32.8 \mathrm{C}$ while minimum temperature ranged from $22.8^{\circ} \mathrm{C}$ to $23.8^{\circ} \mathrm{C}$. Highest temperature was $32.8{ }^{\circ} \mathrm{C}$ for May, while the lowest temperature was $29.5^{\circ} \mathrm{C}$ for August. In Ibadan from Mean Maximum Temperature from May to August, 2015 ranged from $28^{\circ} \mathrm{C}$ to $33^{\circ} \mathrm{C}$ while minimum temperature ranged from $22^{\circ} \mathrm{C}$ to $24{ }^{\circ} \mathrm{C}$. The highest temperature was in June $\left(33^{\circ} \mathrm{C}\right)$, while $\mathrm{Au}$ gust had the lowest temperature of $22^{\circ} \mathrm{C}$ (Table 2). At Abeokuta from (May to August 2015), relative humidity ranged from $61.9 \%$ to $73 \%$ (Table 2). Highest relative humidity was in June $70.8 \%$ while the lowest was $61.9 \%$ in May at Ibadan from (May to August 2015). Relative humidity ranged from $82 \%$ to $92 \%$. Highest relative humidity was $92 \%$ August while the lowest value $(82 \%)$ was in July.

\section{Physico-Chemical properties of the soil.}

The soil in the experimental sites in Ibadan and Abeokuta were sand with high proportion of sand (927.0 and $879.0 \mathrm{~g} / \mathrm{kg}$ ) with 37.6 and $74.9 \mathrm{~g} / \mathrm{kg}$ silt, 35.4 and $46.1 \mathrm{~g} / \mathrm{kg}$ clay respectively (Table 3 ). The $\mathrm{pH}$ of the soil in both locations in 2015 was 6.53 and 6.45 respectively. The soil at Abeokuta experimental site had higher nitrogen $(0.8 \mathrm{~g} /$ $\mathrm{kg})$ than that of Ibadan $(0.7 \mathrm{~g} / \mathrm{kg})$ though it was below the sufficient rating level for the test crop, the same trend was also observed

\section{E ffect of variety, types and rates of or- ganic fertilizers on chlorophyll content of okra at Abeokuta and I badan during 2015 planting season}

The organic foliar fertilizer rate had significant ( $p \leq 0.05)$ effect on the chlorophyll content of the O kra while fertilizer type, variety and their interactions was not significant on the chlorophyll content of the okra varieties (Table 4). However, variety LD 88 had higher chlorophyll content in Abeokuta (46.84) than variety NHae47-4 in the two locations. The foliar organic fertilizer D.I green irrespective of time and location had higher chlorophyll content on the okra at 4WAS (39.42), 6WAS (46.57) and 8WAS (43.04) hence performed better in Ibadan. Conversely, in Abeokuta it was D .I grow red that had higher chlorophyll content on the okra irrespective of time and location at 4WAS (40.68), 6WAS (45.96) and 8WAS (41.34)

Foliar organic fertilizer rate $300 \mathrm{ml} /$ ha had higher yield of chlorophyll content in Abeokuta at 4WAS (43.08),6WAS (47.47) and 8WAS (42.49). In Ibadan, it was foliar organic fertilizer rate $900 \mathrm{ml} /$ ha that had higher chlorophyll content on the okra at 4WAS (41.15), 6WAS (47.75) and while at 8WAS it was foliar organic fertilizer rate $300 \mathrm{ml} /$ ha had higher yield of chlorophyll content (44.39) as shown in Table 4. 


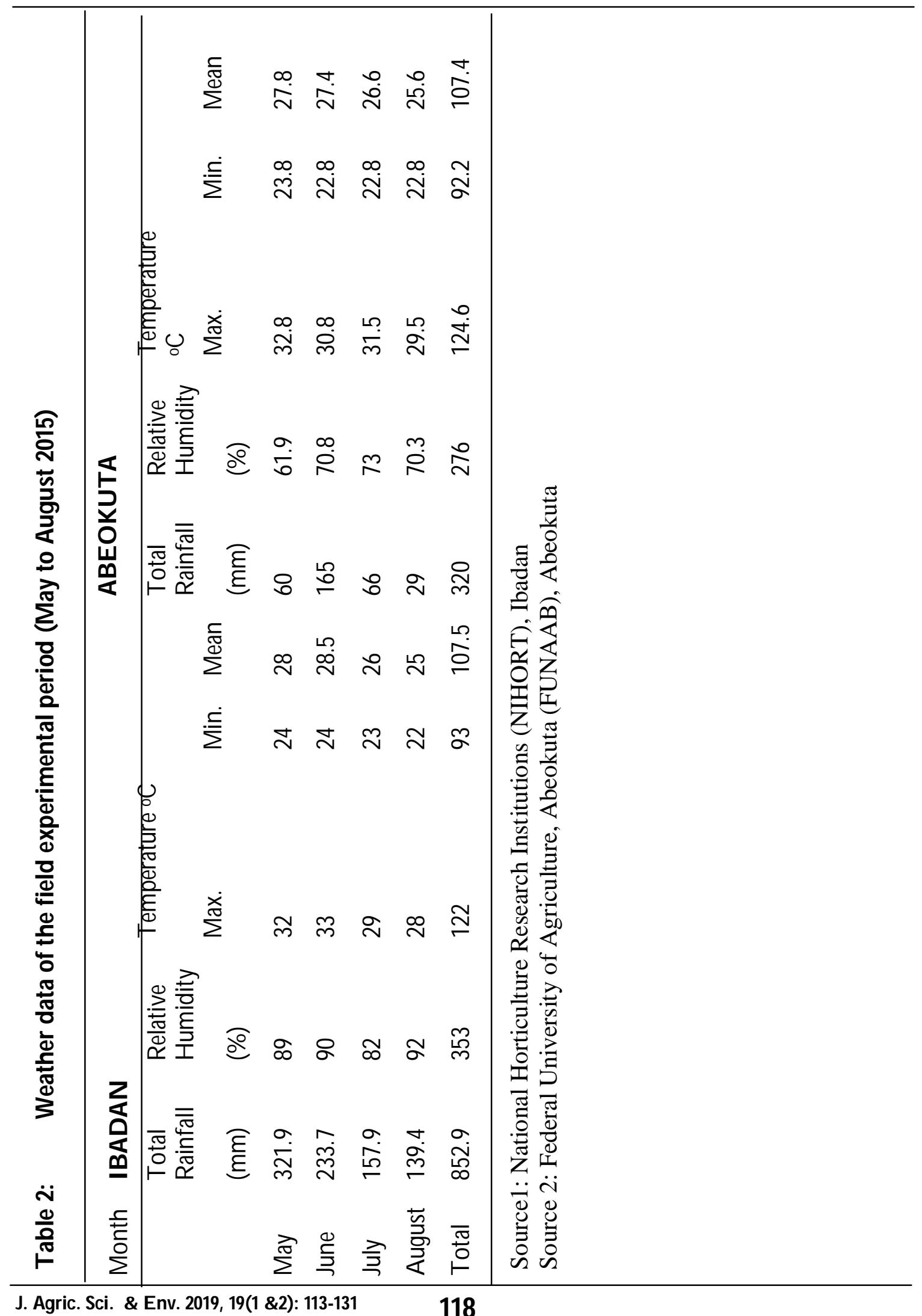


EFFECT OF ORGANO - BASED FOLIAR FERTILIZER ON CHLO ROPHYLL AND ...

Table 3: Pre-plant soil physio- chemical properties of experimental sites during 2015 planting season

\begin{tabular}{|c|c|c|}
\hline Soil Properties & IBADAN & ABEOKUTA \\
\hline Soil ${ }_{\mathrm{p}} \mathrm{H}$ & 6.5 & 6.5 \\
\hline $\mathrm{Ca}(\mathrm{cmol} / \mathrm{kg})$ & 2.6 & 2.5 \\
\hline $\mathrm{Mg}(\mathrm{cmol} / \mathrm{kg})$ & 0.6 & 0.7 \\
\hline $\mathrm{Na}(\mathrm{cmol} / \mathrm{kg})$ & 0.3 & 0.3 \\
\hline $\mathrm{K}(\mathrm{cmol} / \mathrm{kg})$ & 0.4 & 0.4 \\
\hline Exch acidity $(\mathrm{cmol} / \mathrm{kg})$ & 0.7 & 0.1 \\
\hline ECEC (cmol/ kg) & 4.0 & 3.9 \\
\hline Total N (g/ kg) & 0.7 & 0.8 \\
\hline Organic C (g/ kg) & 5.8 & 6.5 \\
\hline Av.P (mg/kg) & 4.9 & 5.2 \\
\hline Mn (mg/ kg) & 7.5 & 8.1 \\
\hline $\mathrm{Cu}(\mathrm{mg} / \mathrm{kg})$ & 0.4 & 0.3 \\
\hline Zn (mg/ kg) & 1.5 & 1.6 \\
\hline $\mathrm{Pb}$ (mg/ kg) & 0.3 & 0.3 \\
\hline Cd (mg/ kg) & 0.004 & 0.006 \\
\hline Sand (g/ kg) & 927.0 & 879.0 \\
\hline Silt (g/ kg) & 37.6 & 74.9 \\
\hline Clay (g/ kg) & 35.4 & 46.1 \\
\hline Soil texture & Sand & Sand \\
\hline
\end{tabular}




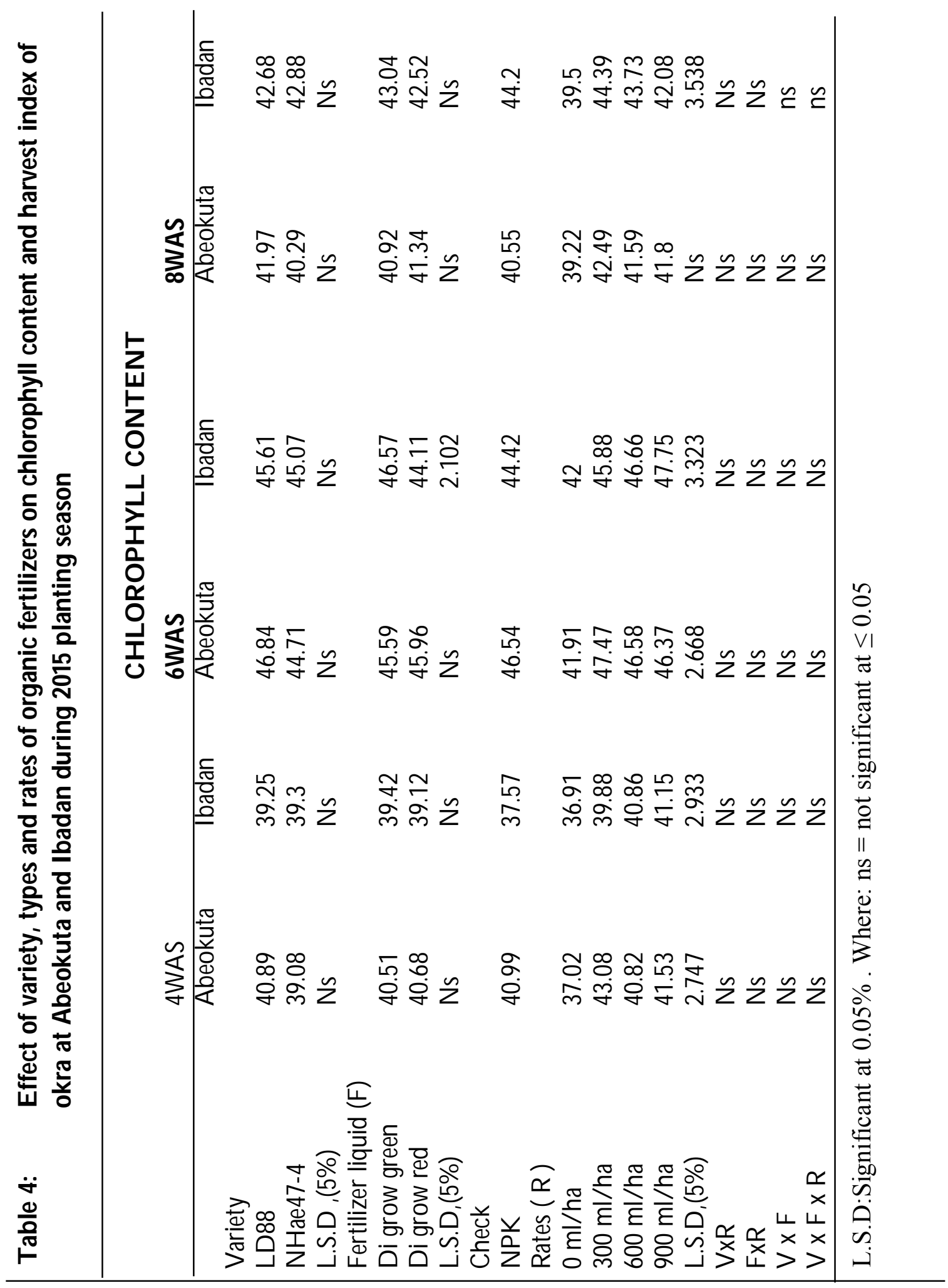

J. Agric. Sci. \& Env. 2019, 19(1\&2): 113-131 120 
EFFECT OF ORGANO - BASED FO LIAR FERTILIZER ON CHLOROPHYLL AND ...

E ffect of variety, types and rates of organic fertilizers on $\%$ ash, $\%$ fat, $\%$ crude fiber and \% crude protein, \%moisture content and \%carbohydrate content at Abeokuta and I badan during 2015 planting season.

In both locations, significant difference ( $\mathrm{p}$ $\leq 0.05)$ on the proximate analysis were recorded. The organic fertilizer D.I grow red performed better while D .I grow Green had the least performance in Abeokuta. There was a significant different $(\mathrm{P} \leq 0.05)$ in the ash in both locations. In Abeokuta, rate of $300 \mathrm{ml} /$ ha had ash content of $9.4 \%$, followed by plants fertilized with $900 \mathrm{ml} / \mathrm{ha}$, (7.9\%) while the unfertilized plant had ash of $5.8 \%$. In Ibadan, rate of $300 \mathrm{ml} /$ ha had ash content of $8.6 \%$ while the check NPK $15: 15: 15$ was $8.5 \%$ followed by the unfertilized plant $5.6 \%$.

In Abeokuta $0 \mathrm{kra}$ fat at the rate of $600 \mathrm{ml} /$ ha was 3.0\% followed by plants fertilized with $900 \mathrm{ml} /$ ha $(2.5 \%)$ and the check N.P.K was $2.2 \%$ while the unfertilized plant had $1.8 \%$ fat. In Ibadan, rate of $900 \mathrm{ml} /$ ha gave Fat of $2.7 \%$, followed by $300 \mathrm{ml} / \mathrm{ha}$, $(2.6 \%)$ and rate $600 \mathrm{ml} /$ ha $(2.5 \%,(2.4 \%)$ for NPK while the unfertilized plant was $1.7 \%$.

Different crude fibre were recorded at different rate of organic foliar fertilizer applied. O kra in Abeokuta, at the rate of 300 $\mathrm{ml} /$ ha had $15.9 \%$ crude fibre, followed by with plants that received organic foliar fertilizer of $600 \mathrm{ml} /$ ha $(13.6 \%)$ and $900 \mathrm{ml} / \mathrm{ha}$ $(13.6 \%)$ while N.P.K and the unfertilized plant had $13.3 \%$ and $9.0 \%$ crude fibre respectively. In Ibadan, rate of $300 \mathrm{ml} /$ ha had crude fibre of $15.2 \%$ followed by plants fertilized with organic foliar fertilizer of 600 $\mathrm{ml} /$ ha and N.P.K 15:15:15 which were $15.1 \%$ respectively. Table 5.

Okra in Abeokuta, at N.P.K 15:15:15 gave crude protein content of $18.3 \%$ followed by plants fertilized with $900 \mathrm{ml} / \mathrm{ha}(18.1 \%)$. While other rates $600 \mathrm{ml} / \mathrm{ha}(16.6 \%)$ and $300 \mathrm{ml} / \mathrm{ha}(16.1 \%)$ were recorded. In Ibadan, rate of $900 \mathrm{ml} / \mathrm{ha}$ had Crude Protein of (20.2\%) followed by plants fertilized with N.P.K 15:15:15 (19.5\%) Crude Protein. Other rates $300 \mathrm{ml} / \mathrm{ha}(18.3 \%)$ and $600 \mathrm{ml} /$ ha $(17.12 \%)$ were recorded while the unfertilized plant had $11.2 \%$. (Table 5)

Moisture content of okra in Abeokuta, at the rate of $300 \mathrm{ml} / \mathrm{ha}$ had $9.1 \%$ followed by plants fertilized with N.P.K 15:15:15 $(8.9 \%)$, Other moisture content with other rates are $8.8 \%$ at $600 \mathrm{ml} / \mathrm{ha}, 8.7 \%$ at 900 $\mathrm{ml} / \mathrm{ha}$, while the unfertilized plant had $4.7 \%$. In Ibadan, rate of $600 \mathrm{ml} / \mathrm{ha}$ and 900 $\mathrm{ml} / \mathrm{ha}$ had moisture content of $8.9 \%$ followed by plants fertilized with $300 \mathrm{ml} / \mathrm{ha}$ and N.P.K 15:15:15 (8.8\%). Moisture content with the unfertilized plant was $(4.7 \%)$. (Table 5).

Carbohydrate content of okra from Abeokuta, at the rates of $300 \mathrm{ml} /$ ha had $(52.0 \%)$ followed by plants fertilized with $600 \mathrm{ml} / \mathrm{ha}$ $(51.2 \%)$. Carbohydrate content with other rates is $(49.2 \%)$ at $900 \mathrm{ml} / \mathrm{ha},(44.5 \%)$ with N.P.K 15:15:15 and the unfertilized plant had $(26.8 \%)$. In Ibadan, rate of $600 \mathrm{ml} /$ ha had $(48.0 \%)$ followed by plants fertilized with $300 \mathrm{ml} /$ ha $(46.6 \%)$. other rates are $(45.6 \%)$ with NPK 15:15:15, (45.0\%) at 900 


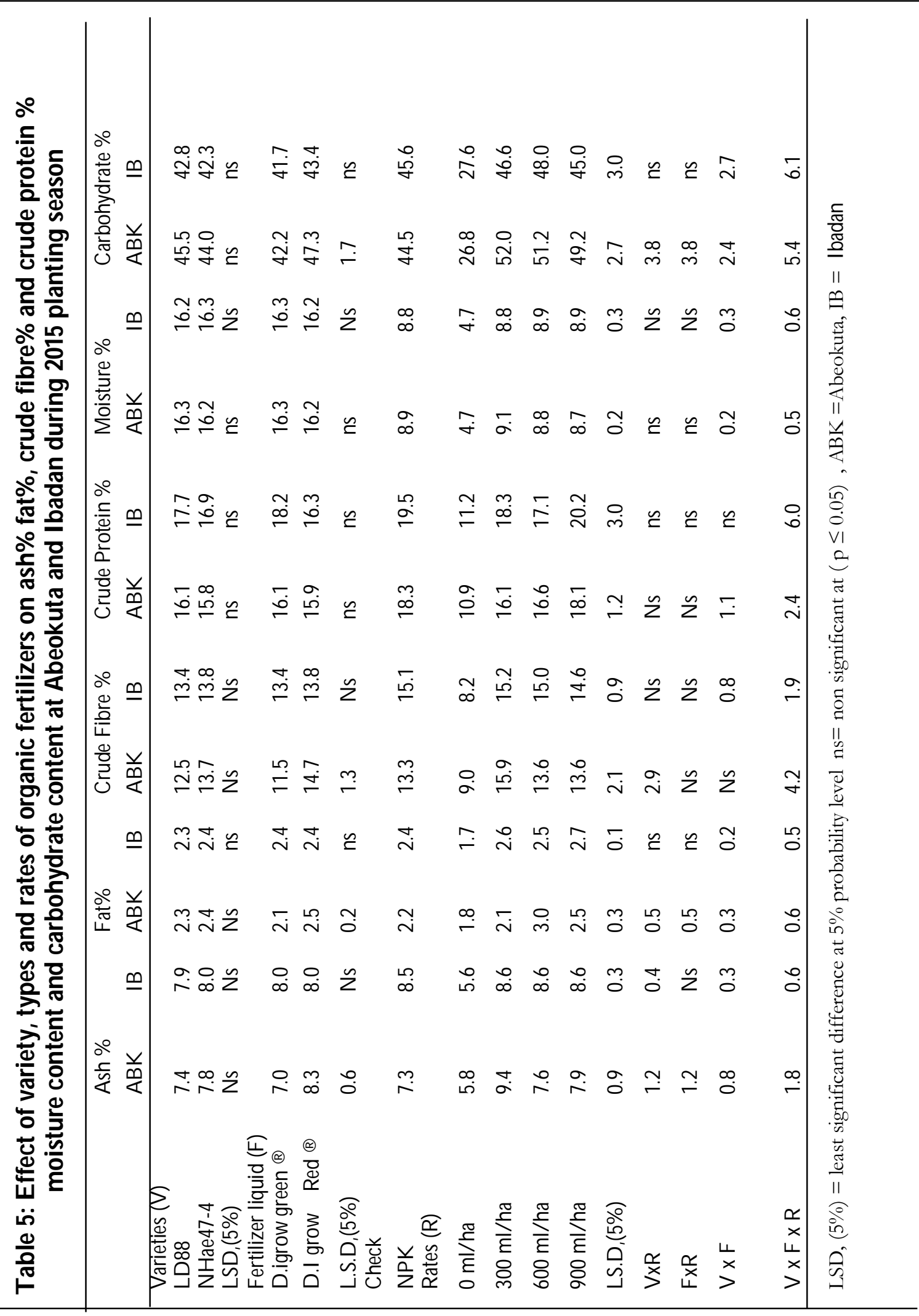


EFFECT OF ORGANO - BASED FO LIAR FERTILIZER ON CHLOROPHYLL AND ...

E ffect of Interaction between varieties and rates on proximate analysis of $\%$ ash, fat, crude fiber and carbohydrate content in Abeokuta and Ibadan

The interaction effect $(\mathrm{p} \leq 0.05)$ between varieties and rates (Table 6) on ash content at the rate of $600 \mathrm{ml} / \mathrm{ha}$ had variety NHae47-4 ash content ( 9.42\%), followed by $900 \mathrm{ml} / \mathrm{ha},(9.13 \%)$, the other rate are $6.23 \%$ at $300 \mathrm{ml} / \mathrm{ha}, 6.18 \%$ at N.P.K; and the unfertilized had $6.04 \%$.Variety LD 88, at rate of $300 \mathrm{ml} /$ ha had ( 9.32\%), followed by $600 \mathrm{ml} / \mathrm{ha},(9.06 \%)$ while N.P.K $15: 15: 15$ with a value of ( $8.4 \%)$ and the unfertilized plant ( $5.59 \%$ ) recorded the least values of $\%$ ash.

In Ibadan, variety NHae47-4 gave ash content at the rates of $300 \mathrm{ml} /$ ha $(9.07 \%)$, followed by $900 \mathrm{ml} /$ ha $(8.67 \%)$, the other rate N.P.K 15:15:15 (8.50\%) and $600 \mathrm{ml} / \mathrm{ha}$ (8.37\%), while the unfertilized had $5.62 \%$. The other variety, LD 88, at rate $300 \mathrm{ml} /$ ha had ash content of (8.73\%), followed by plant fertilized with $600 \mathrm{ml} /$ ha of $(8.66 \%)$. The other rate at $900 \mathrm{ml} /$ ha had $(8.55 \%)$, and N.P.K 15:15:15 (8.21\%) while the unfertilized plant had 5.49\% (Table 6).

In Abeokuta, percentage fat content from variety LD 88 when treated with N.P.K $15: 15: 15$ was $(2.95 \%)$ followed by $600 \mathrm{ml} /$ ha, $(2.63 \%)$. Other rates $900 \mathrm{ml} /$ ha were (2.63\%) while the unfertilized was $(1.62 \%)$. In NHae47-4, N.P.K 15:15:15 produced (3.03\%) followed by $(2.85 \%)$ at $900 \mathrm{ml} / \mathrm{ha}$ and unfertilized had $(1.74 \%)$. On percentage Crude fiber(cf) content in Abeokuta, variety NHae47-4 at rate of $600 \mathrm{ml} /$ ha foli- ar organic fertilizer produced crude fibre (16.30\%), followed by $300 \mathrm{ml} / \mathrm{h}$ ha of $15.91 \%$, other rate N.P.K 15:15:15 was $15.72 \%$.The unfertilized plant had $8.87 \%$ crude fibre. The variety LD 88, at rate of $900 \mathrm{ml} /$ ha gave (16.20\% cf), followed by N.P.K 15:15:15 of (16.16\% cf). The other rate $600 \mathrm{ml} /$ ha gave $(10.82 \mathrm{cf})$ and $300 \mathrm{ml} /$ ha gave $(10.69 \% \mathrm{cf})$ while the unfertilized was $9.15 \% \mathrm{cf}$. O n carbohydrate content, rate of $300 \mathrm{ml} /$ ha on variety LD 88 gave (56.16\%), followed by 600 $\mathrm{ml} /$ ha, which had (55.73\%) while the unfertilized had $25.79 \%$. Variety NHae47-4 when treated with $900 \mathrm{ml} /$ ha produced ( 53.29\%), followed by $300 \mathrm{ml} /$ ha, (47.87\%).Other rate $600 \mathrm{ml} /$ ha had $46.75 \%$, N.P.K 15:15:15 $(44.32 \%)$ and the unfertilized had $27.78 \%$ as seen in Table 6.

\section{Interaction effect of fertilizer type and rates on percentage $(\%)$ ash content:}

Interaction effect of fertilizer type and rates on percentage (\%) ash content in Abeokuta

The interaction effect $(p \leq 0.05)$ of fertilizer type and rates on crude ash content are shown on Table 7. D .I grow green fertilizer at rate of $300 \mathrm{ml} /$ ha had highest value of percentage ash content $(9.37 \%)$. This was followed by the rate of $300 \mathrm{ml} /$ ha $(9.36 \%)$ from D.I grow Red while the least percentage ash content was recorded in the control plant. In the fat content, D.I grow green at rate of $900 \mathrm{ml} /$ ha had the highest percentage value of crude fat $2.85 \%$ and was closely followed with $2.65 \%$ crude fat from rate of $600 \mathrm{ml} / \mathrm{ha}$. The percentage carbohydrate showed that D.I grow Red at rate of $300 \mathrm{ml} / \mathrm{ha}$ and $600 \mathrm{ml} /$ ha had value of $56.02 \%$ and $56.31 \%$ respectively. 


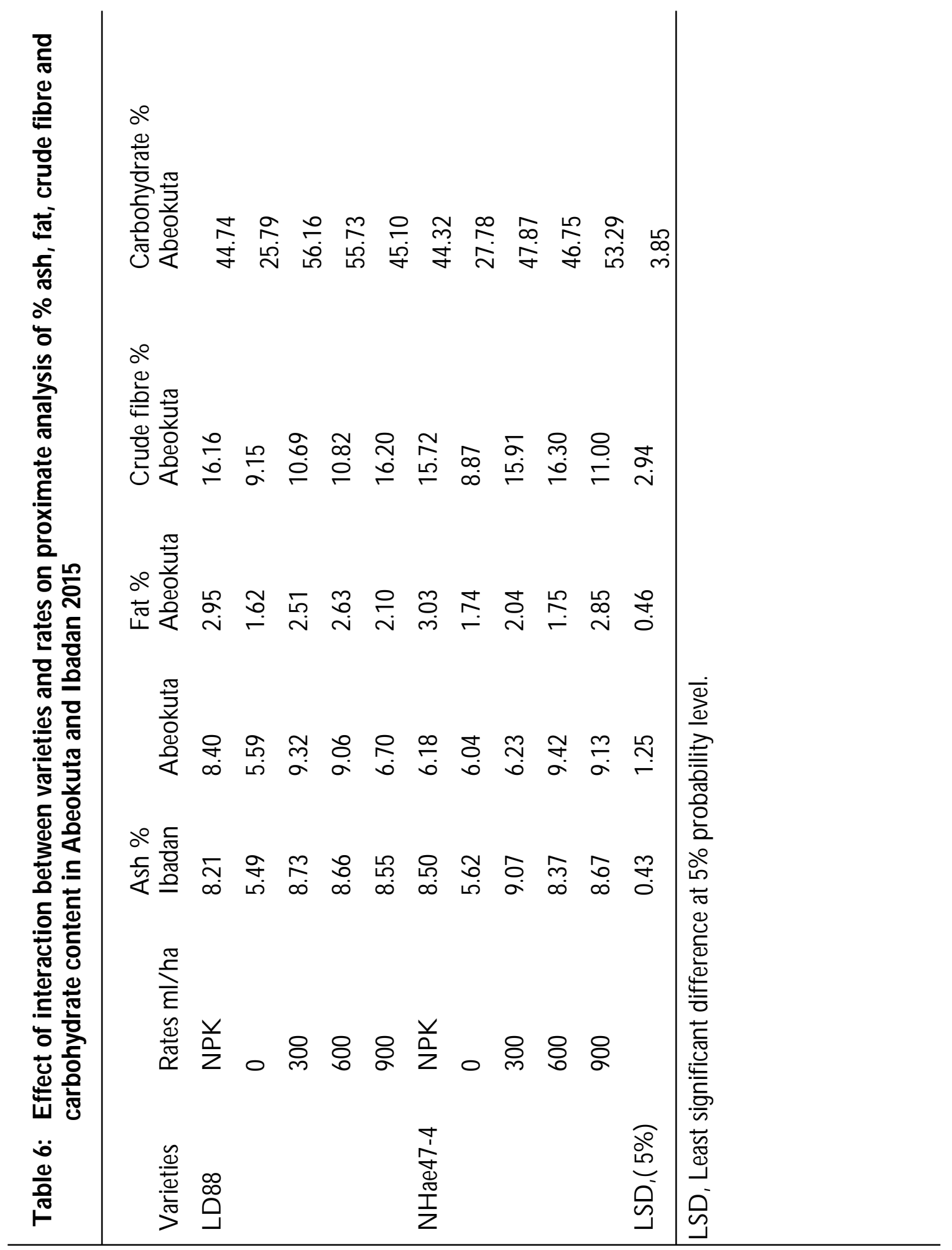


EFFECT OF ORGANO - BASED FO LIAR FERTILIZER ON CHLO ROPHYLL AND ...

Table 7: Effect of interaction between fertilizer and rates on \% ash, fat and carbohydrate content in Abeokuta 2015

\begin{tabular}{lllll}
\hline \multirow{2}{*}{ Fertilizer } & Rates ml/ ha & ABEOKUTA & \\
& NPK & 8.43 & Fat\% & Carbohydrate \% \\
\hline & 0 & 5.58 & 1.74 & 44.53 \\
& 300 & 9.37 & 2.49 & 47.72 \\
& 600 & 8.68 & 2.67 & 46.47 \\
D.I grow Green & 900 & 9.18 & 2.85 & 44.75 \\
& NPK & 6.20 & 2.99 & 44.53 \\
& 0 & 6.05 & 1.71 & 26.02 \\
& 300 & 9.36 & 1.76 & 56.31 \\
LSD ,( 5\%) & 600 & 6.56 & 1.92 & 56.02 \\
\hline
\end{tabular}

LSD: Least significant difference at $5 \%$ probability level

E ffect of interaction between varieties and fertilizer on proximate analysis of $\%$ ash, fat moisture, carbohydrate, crude protein and fibre contents in Abeokuta and Ibadan.

In Abeokuta, the interaction effects of varieties and fertilizer on the nutritive content of okra showed that application of D.I grow Green on both varieties (LD 88 and NHae47-4) had the highest percentage Ash content of $8.96 \%$ and $7.5 \%$ respectively. However, in Ibadan it was D.I grow Red that had highest percentage ash content of $8.68 \%$ and $8.58 \%$ on the two varieties of NHae47-4 and LD 88 respectively. The percentage content of fat does not follow this trend. In Abeokuta, D.I grow RED had higher \% fat (2.83\%) on LD 88 while on the other variety NHae47-4, D.I grow RED had higher \% fat $(2.30 \%)$ content. Similar trend as above was observed in Ibadan in both varieties.

The percentage moisture content irrespective of location and varieties the trend above was observed. In variety LD 88, D.I grow RED had higher moisture content $23.53 \%$ and $23.75 \%$ in both location Abeokuta and Ibadan respectively. Also D.I grow Red had higher moisture content $9.01 \%$ and 8.92\% in the variety (NHae47-4) in Abeokuta and Ibadan respectively. In both Abeokuta and Ibadan, D.I grow Red had higher percentage carbohydrate $53.75 \%$ and $46.89 \%$ with LD 88, while with NHae47-4, in Abeokuta D.I grow Green was best with a value of $45.71 \%$ and in Ibadan D .I grow Red was the best with percentage carbohydrate of $39.99 \%$.

In percentage protein and fibre content, D .I grow green had higher protein and fibre value content of $14.71 \%$ and 14 96\% respectively in variety NHae47-4 both in Abeokuta and Ibadan. In variety LD 88, D.I grow Green had higher percentage of protein $(17.88 \%)$ content while higher percentage fibre content $14.78 \%$ was recorded with D.I grow Red. (Table 8) 


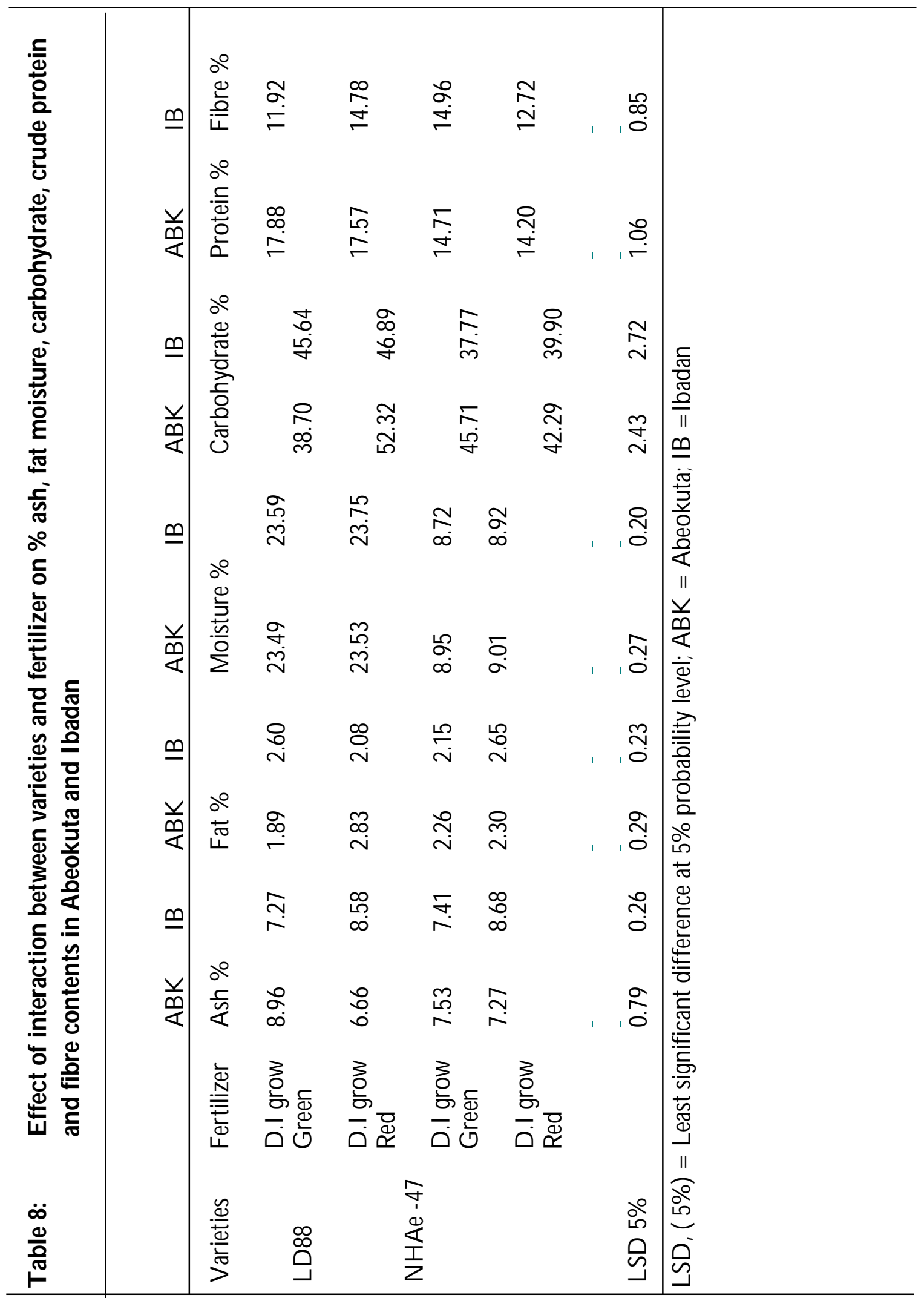


EFFECT OF ORGANO - BASED FO LIAR FERTILIZER ON CHLO ROPHYLL AND ...

\section{DISCUSSION}

The soil texture of the experimental site by United State Development Association soil classification sandy texture, this texture may be attributed to parent material (PM) from which the soil was formed and the climate of the area. The soil texture might be formed from sandstone and quartz parent material in this environment thus sandy texture of the soil. This is in line with the findings of Brady and Weils (1999) that the high sand content of soil could be attributed to high content of quartz and sandstone in the parent material.

Weather condition affected the two varieties, the chlorophyll and their nutritional content especially in Ibadan. This is due to higher rainfall and relative humidity with lower temperature in Ibadan compared to Abeokuta. This might have significantly affected the effectiveness of the D.I Grow plus organic fertilizer. Though, the observed quantum of rainfall during the experimental period was below the crop rainfall requirement in Abeokuta and above in Ibadan as reported by Dada and Fayinminnu (2010) for okra cultivation. The observed temperatures during the period of the experiment were within the range of temperature requirement for the optimum performance of the crop as reported by Tindall (1983). The soil pH though almost neutral and was within the favorable range for crop cultivation, but its fertility status was poor as a result of torrential rainfall and bad weather condition that characterize generally the tropical soils (Prochnow, 2008).

The liquid fertilizer, rich in both macro and micro nutrients were applied to enhance both chlorophyll and the nutritional quality of the okra. Foliar organic fertilizer is considered as a supplement to the application of nutrients under adverse soil and environmental situations, low soil nutrients bioavailability, hard top soil, and decreased root activity during the vegetative and reproductive growth stage of plants (Naruka \& al., 2000; Alkaff and Hassan, 2003). It is opined that it helped timely translocation of deficient nutrients to plant system through leaf tissue (Chattopadhyay \& al., 2003; Fageria \& al., 2009).

The observed chlorophyll content in the plant and nutritional quality of the two varieties despite the unfavorable weather condition in both location of the field may be due to the role of macro and micro nutrients in the physiological process, cell division and elongation which indirectly affected the tissue formation and consequently vegetative growth and the reproductive stage of the crop. These results corroborate the work of Abdul Rasool \& al., 2010 and Kadum,2011 when plant are under some adverse weather conditions physiological process of the plant are slow down that gears towards growth and development. Hence, D .I grow plus liquid fertilizer maybe good fertilizer to make up for bad weather condition for survival of crop especially when water and minerals were not readily available to the growing crop (Kadum,2011; Sharma and Kumawat, (2011).

The similar trend values obtained in the proximate parameters content may also be attributed to the organo-based foliar fertilizer applied.

The parameters that were measured in Abeokuta under the application rate of $300 \mathrm{ml} / \mathrm{ha}$ performed better than the other application rate. While at Ibadan, higher rate $600 \mathrm{ml} /$ ha and $900 \mathrm{ml} /$ ha had better application performance, though the rate $600 \mathrm{ml} /$ ha maybe 
economical. This may connected to the interaction between genetic makeup of the crop, climatic factor and environmental factor which is line with Adejonwo \& al. (1989); Burnside (1993); Dikwahal \& al. (2006) Adeyemi \& al (2008), and Iyagba \&al (2013) who reported that the limiting factors to okra production and other vegetables are many; such as soil type in the different location, genetic makeup of the crop, ability to use different nutrient minerals at different rate of concentration and also be able to partition the nutrients from the sources to sink (pods). Thus at different concentration in same place, different physiological manifestation by plant may be visible.

\section{CONCLUSION AND RECOMMEN DATION}

The liquid fertilizer was rich in both micro and macro nutrients. It was able to supply sufficient nutrients to enhance chlorophyll and proximate content at different rate and at different location. It was also observed that D.I grow Green and Red had a similar effect on the parameters of okra at different location. However, D .I grow GREEN fertilizer at the rate of $300 \mathrm{ml} /$ ha had higher performance on all the parameters in Abeokuta while in Ibadan the rate of $600 \mathrm{ml} /$ ha had higher performance on the parameters. It is therefore recommended that application of $300 \mathrm{ml} / \mathrm{ha}$ and $600 \mathrm{mls} / \mathrm{ha}$ D.I grow fertilizer could be employed by farmers in Abeokuta and Ibadan respectively.

\section{REFERENCES}

Abdul Rasool I.J; K.D. H. Al-Jebory., F.H. Al-Sahaf. 2010. Effect of Foliar Application of Unigreen and Solu Potash on Yield and Quality of Potato Tuber. Jordan Jomal of Agiaultural Saience 6(1):111 - 119.
Adeboye, 0.C., Oputa, C.0. 1996. Effect of Galex on Growth and Fruit Nutrient Composition of O kra (Abdmoshus esalentus) IfeJaumal of Agiaulture18 (1\&2): 1 - 9.

Adeyemi, 0.R., Smith, M.A. K., Ojeniyi, S.0. 2008. Effect of Land Preparation Techniques on Weed Control Effectiveness in O kra (Abdmoschus esalentus L) Moench. Nige nianJaumal of Weed Saience(21):72-83

Akpambang, V.0., Amoo, E., Izuagie, I.A. 2008. Comparative Compositional Analysis on Two Varieties of Melon (Cdooythis atrullus and Cuameropsis) and a Variety of Almond (Prunus amygdalus). Resarce Jaumal of Agiaultural Bidogical Säene(4): 639-642.

Alkaff, H. A., Hassan, A. A. 2003. Effect of Bio- fertilizer, Organic Fertilizer and Foliar Application of Power 4 on the Growth and Yield of Okra Plants. Jaumal of National Applied Saienes 7 (2): 25-35.

Association of 0 fficial Analytical Chemists (AOAC) 1990.0 fficial Methods of Analysis of the Association of the Official Analytical Chemists. 18th Edition., Washington DC.

Babatunde, R.0., Omotosho, O.A., Sholatan, O.S. 2007. Socio-economic Characteristics and Food Security of Farming Households in Kwara State, North-Central Nigeria. Pakistain Jaumal of Nutrition (6): 4958.

Bakhru, H.K. 2003. Foods that hell: TheNatural way to goodhelth O rient paperbacks, D elhi, pp 82 - 90.

Bamire, A.S., O ke, J.T. 2003.Profitability of Vegetable Farming under Rainy and D ry Season Production in Southwestern Nigeria. 
EFFECT OF ORGANO - BASED FO LIAR FERTILIZER ON CHLO ROPHYLL AND ...

Jamal of VegtableCropProduction(9):11 - 18 Brady, C. and Weils, R. R. 1999.Nature and Properties of Soil, Twelfth Edition, Prentice Hall, New D elhi pp 74 - 114.

Burkil, H.M. 1997. The Useful Plants of West Africa 2nd Edition. Volume 4, Families M-R, Royal Botanical Garden. Kew United Kingdom. pp. 969

Chattopadhyay, S. B., Mukhopadhyay, T. P., Thapa, U. 2003. Response of Foliar Feeding of Boron and Molybdenum on Growth and Yield of $\mathrm{O}$ kra in Terai Zone of West Bengal Eniramental Eodogy 21 (3): 702-705.

Dada, 0. A., Fayinminnu, 0.0. 2010. Period of Weed Control in Okra (Abdmoshus callentus(L.) Moench) as Influenced by Varying Rates of Cattle D ung and Weeding Regimes. Nctulae Bdtanicae Hati Agrodanidi- Napoca (38): 149 -154.

Dikwahal, H.D., Haggai, P.T., Aliyu, L. 2006. Effects of Sowing Date and Plant Population D ensity on G rowth and Yield of Two O kra (Abdmoshus ealestus L.) Varieties in the Northern Guinea Savanna of Nigeria. Nigrian Jamal of Hartialtural Saiere (11): 56-62.

Dynapharm Intenational Manual. 2003 In: Organic Plus Fertilizer Dynapharm "Health is Wealth" 2016.

Edet, G.E., Etim, N.A. 2007. Gender Role in Fluted Pumpkin (Tefeia ocidantalis) Production in Akwa Ibom State. Proceedingof the 41st Annual Confereme of the Agialtural soidy of Nigria (ASN) pp 612 - 615.

Eke, K.A., Essien, B.A., Ogbu, J.U. 2008. Determination of Optimum Planting
Time of okra (Abdmoschusesalantus) Cultivars in the Derived Savannah. Proceedings of the 42nd Annual Confereme of Agiailtural Sociey of Nigria (ASN). Pp 242 - 245.

Fagenia, N. K., Filhoa, M. P. B., Moreirab, A., Guimaresa, C. M. 2009. Foliar Fertilization of Crop Plants. Jaumal Plant Nutrition32 (6): 1044 -1064.

Farinde, A. J., Owolarafe, O. K., Ogungbemi, 0. I. 2001. An Overview of Production, Processing, Marketing, and Utilization of O kra in Egbedore Local Government Area of O sun State, Nigeria. Agricultural Engineering International. The CIGR E Jamal,,Volume 4 pp.1-17.

Fashina, A.S., O latunji, K.A., Alasiri K.0. 2002. Effect of D ifferent Plant Populations and Poultry Manure on the Yield of Ugu (Tefaira ocidatalis) in Lagos State, Nigeria, In: Proceedings of Annual Conference of Horticultural Society of Nigeria (HORTSO N), 14- 17th May 2002; NIHORT Ibadan, Nigeria.

Iyagba, A.G., Onuegbu, B.A., Ibe , A.E. 2013. Growth and Yield Response of O kra (Abdmoshus esualestus (L.) Moench) to NPK Fertilizer Rates and Weed Interference in South Eastern Nigeria. Intemational Resarces Jaumal of Agiailtural Saiene and Sail Säene 3 (9): 328 - 335.

Kadum, E.A.H. 2011. Effeet of Spraying Organic Fetilizer on Gronth and Yidd of three Pdato Cultivar. M.Sc. Thesis in Agric College, Busogo Campus. Kufa University.

Kannan, S. 2010. Foliar Fertilization for Sustainable Crop Production. SustainableAg vialture reviens, Gentic Engneering Bio fertiliza tion Sail qualityand OrganicFaming 4 (6): 371- 
Nanuka, I. S., Gujar, K.D., Lal, G. 2000. Effect of Foliar Application of Zinc and Molybdenum on $\mathrm{G}$ rowth and Yield of O kra (Abdmoschus esaletus L. Moench) Pusasawani Haryana. Joumal of Hotialtural Saience, 29 (3/ 4): 266-267.

National Research Council (NRC) 2006. Lost Crops of Africa: Volume 11: Vegetable, National A cademic Press. Washington DC. USA ISBN : 0-309-66582- (5): 378.

Naz, R. M., Muhammad, S., Hamid, A., Bibi F. 2012. Effect of Boron on the Flowering and Fruiting of Tomato. Sarhad Joumal of Agialture28(1): 37-40

Ngbede SO, Ibekwe HN, Okpara SC, Onyegbule, U.N., Adejumo L, 2014.An Overview of Okra Production, Processing, Marketing, Utilization and Constraints in Ayaragu in Ivo Local Government Area of Ebonyi State, Nigeria. Greener Jaumal of Agialtural Saiences 4(4):136-143.

Okalebo, J.R., Gathua, K.W., Woomer, P.L., 1993. Labaratary Methook of Sail and Plant Analysis A Working Manual. Nairobi: Tropical Soil Biology and Fertility Programme.

Omotoso S.0., Shittu O.S. 2007. Effect of NPK Fertilizer Rates and Method of Application on Growth and Yield of O kra (Abdmoschus salentus(L.) Moench) at AdoEkiti Southwestern, Nigeria. Intemational Jaumal of Agialtural Rescarch(2): 614-619.

Palm, C.A., Myer, J.K., Nandwa, S.M. 1993. Combined Use of Organic and Inorganic Nutrient Sources for Soil Fertility Maintenance and Replenishment. Säl Saiene
Sociey of America Special Publication (51): 193217.

Pearson, D. H., Egan, R.S. Kirk., R. Sawyer, 1981.Pearson's Chemical Analysis of Food. Edinburgh: Churchill Livingston.

Prochnow, L.I. 2008. Optimizing Nutrient Use in Low Fertility Soils of the Tropics. Better Crops 92(3):19 - 21 http:// www.ipni.net/ bettercrops

Reuveni, M., Reuveni, R. 1995. Efficacy of Foliar Sprays of Phosphates in Controlling Powdery Mildews in Field Grown Nectarine, Mango Trees and $\mathrm{G}$ rapevines. Crop Protetion. (14): $311-314$

Schippers, R.R. 2000. Africa Indigenous Vegetable an Overview of the Cultivated Species. National Resources Institute (NRI), University of $\mathrm{G}$ reenwich, London, United Kingdom, pp 214.

Sharma, R.K., Kumart, M. 2011. Journal of Enviranmental Bidogy (26): 301-313.

Shukla, V., Nailk, L.B. 1993.AgoTehnique for Malvacea Veetables In: Ifovance in horticulture, Volume 5. Malhotra publishing house, New D elhi, India, pp 399-425.

Siemonsma, J.S. 1982. The Cultivation of Okra (Abdmoshus spp.), Tropical FruitVegetable (with special reference to the Ivory Coast). D .H.O. Thesis, Wageningen Agricultural University Wageningen, The Netherland. pp 297.

Tindall. H. D. 1983. Vegetables in the Tropics. McMillan AVI. pp. 33, 325-327.

Udoh, D.J., Ndon, B.A., Asuquo, P.E., N daeyo, N.U. 2005. Crop Production Teh- 
EFFECT OF O RGANO - BASED FO LIAR FERTILIZER ON CHLOROPHYLL AND ...

niques for the Tropics Concept publisher, La- ment of Economic, Vive Kananda College, gos, Nigeria. pp 223-247.

Puttur Karnataka. Pp:102-131.

Varmudy, V. 2011. Marketing Survey

Needed to Boost Okra Exports. Depart-

(Manuscipt reecived: 4thApril, 2019; accepted 26thMay, 2020). 